\title{
Effect of gold addition on the microstructure, mechanical properties and corrosion behavior of $\mathrm{Ti}$ alloys
}

\author{
Yong-Ryeol Lee • Mi-Kyung Han • Min-Kang Kim • \\ Won-Jin Moon • Ho-Jun Song • Yeong-Joon Park
}

Published online: 16 April 2014

(C) The Author(s) 2014. This article is published with open access at SpringerLink.com

\begin{abstract}
We performed a systematic investigation of the $\mathrm{Ti}-\mathrm{xAu}(x=5,10,15,20$, and $40 \mathrm{wt} \%)$ alloys to assess the effect of addition of element $\mathrm{Au}$ on the microstructure, mechanical properties, and corrosion behavior of commercially pure titanium (cp-Ti). The phase and microstructure were characterized using X-ray diffraction (XRD), optical microscopy, scanning electron microscopy (SEM), and transmission electron microscopy (TEM). The results indicated that the Ti-xAu alloys containing up to $15 \mathrm{wt} \%$ Au showed a hexagonal close-packed $\alpha$-Ti structure, whereas the Ti-xAu alloys containing more than $20 \mathrm{wt} \%$ Au were mainly composed of the $\alpha$-Ti phase and $\mathrm{Ti}_{3} \mathrm{Au}$ intermetallic phase. We also investigated the effect of alloying element Au on the mechanical properties (including Vickers hardness and modulus) and corrosion behavior of Ti-xAu binary alloys. The addition of gold to $\mathrm{Ti}$ improved its hardness. Electrochemical results showed that the Ti-xAu alloys exhibited improved corrosion resistance than cp-Ti.
\end{abstract}

\author{
Y.-R. Lee • M.-K. Han • M.-K. Kim • H.-J. Song • Y.-J. Park ( $ه)$ \\ Department of Dental Materials, MRC for Biomineralization \\ Disorders, School of Dentistry, Chonnam National University, \\ Gwangju 500-757, Korea \\ e-mail: yjpark@jnu.ac.kr \\ Y.-R. Lee \\ e-mail: lyr1366@empal.com \\ M.-K. Han \\ e-mail: mikihan@jnu.ac.kr \\ M.-K. Kim \\ e-mail: sniky785@jnu.ac.kr \\ H.-J. Song \\ e-mail: songhj@jnu.ac.kr
}

W.-J. Moon

Korea Basic Science Institute, Gwang-Ju Center, 300

Yongbong-dong, Buk-gu, Gwangju 500-757, Korea

e-mail: wjmoon@kbsi.re.kr
Keywords Ti-Au alloys $\cdot$ Dental material $\cdot$ Mechanical properties $\cdot$ Microstructure $\cdot$ Corrosion behavior

\section{Introduction}

Favorable mechanical properties including high-specific strength, excellent corrosion resistance both in air and in biological fluids, and high biocompatibility have made titanium (Ti) and titanium alloys suitable for application in dental and medical fields $[1,2]$. However, cp-Ti has several disadvantages, such as low deformability, low wear resistance, and difficulty in manufacturing, welding, and machining [3]. Other drawbacks of Ti are a high melting point $\left( \pm 1,700^{\circ} \mathrm{C}\right)$ and a high reactivity with surrounding impurities such as oxygen and nitrogen at elevated temperatures [4]. Therefore, titanium is still unsatisfactory for practical use. Attempts have been made to develop new titanium alloys with improved mechanical properties and castability by alloying $\mathrm{Ti}$ with a variety of elements. The TiNi (Nitinol) and Ti-6Al-4 V alloy are the most widely used materials $[5,6]$. However, the metal ions, such as $\mathrm{Ni}, \mathrm{Al}$, and $\mathrm{V}$, released from the alloy cause allergic and cytotoxic effects and neurological disorders [7]. Therefore, the search continues for new Ti-based alloys with the desired properties, yet lacking any toxic elements, for dental applications.

Gold is classified as a precious metal and has a much higher standard reduction potential than titanium $(+1.498 \mathrm{~V}$ vs. normal hydrogen electrode at $25^{\circ} \mathrm{C}$ ) [8]. It has been recognized to be a nontoxic and nonallergic element. Historically, gold has been used in dentistry for more than 4,000 years due to its good biocompatibility and versatility [9-12]. The use of Au as an alloying element may help to improve the corrosion resistance and biocompatibility of Ti. Recently, Rosalbino et al. reported the positive influence of $\mathrm{Au}$ addition on the corrosion behavior of Ti [13]. They showed that the corrosion resistance 
of Ti alloy containing $3.6 \mathrm{wt} \%$ Au was similar to or better than that of the Ti-6Al-7Nb alloy currently used as a biomaterial. Takahashi et al. examined the mechanical properties of $\mathrm{Ti}-\mathrm{Au}$ alloys and found that the $\mathrm{Ti}-\mathrm{Au}$ alloys had higher yield strength, tensile strength, and hardness [14]. Oh et al. reported that the cytotoxicities of the $\mathrm{Ti}-\mathrm{Au}$ alloys were similar to that of pure $\mathrm{Ti}$ [15]. They also reported that the fusion temperature was lowered by alloying $\mathrm{Ti}$ with $\mathrm{Au}$, thus facilitating the casting process. Therefore, it was reasonable to employ gold as a strengthening alloying element to improve the clinical performance of cp-Ti. Not only for the mechanical properties, but also the galvanic corrosion is a concern for dental implant systems which are consisted of cp-Ti fixture and noble gold alloy crowns. Therefore, it is important to develop goldcontaining $\mathrm{Ti}$ alloys which better harmonize with the gold crowns and have the favorable bone-bonding ability. Despite the fact that there exists an extensive literature on the fundamental physical metallurgical aspects of $\mathrm{Ti}-\mathrm{Au}$ alloys, studies on the relationship between phase/microstructure and various properties of $\mathrm{Ti}-\mathrm{xAu}$ alloys are still relatively rare, and hence further investigations are needed to provide an in-depth understanding of their mechanical properties.

In the present study, for developing a dental titanium alloy with better mechanical properties and corrosion resistance than cp-Ti, the effect of addition of 5, 10, 15, 20, and $40 \mathrm{wt} \%$ alloying element $\mathrm{Au}$ on the microstructure, mechanical properties, and corrosion behavior of Ti-Au binary alloys was investigated. In this work, "Ti-xAu" will henceforth stand for "Ti-wt\% Au".

\section{Experimental}

\section{Material preparation}

A commercially available cp-Ti (ASTM grade 2, Daito Steel Co. Ltd., Japan) was used as the control titanium material. Experimental Ti-Au alloys (5, 10, 15, 20, and $40 \mathrm{wt} \% \mathrm{Au})$ were prepared by arc melting of the stoichiometric quantities of elements placed on a water-cooled copper hearth using a tungsten electrode under high-purity argon atmosphere. The starting materials (Ti sponge, Alfa Aesar, USA, 99.95\%; Au ingot, LS-Nikko, Korea, 99.99 \%) were used without purification. During the arc-melting procedure, a titanium getter was heated prior to melting the reactant mixture to further purify the argon atmosphere. The samples were remelted several times to promote sample homogeneity. Subsequently, the samples were heat treated using tube furnace under argon atmosphere $\left(99.9999 \%\right.$ ) for $4 \mathrm{~h}$ at $150{ }^{\circ} \mathrm{C}$ below the respective solidus temperatures followed by cooling in furnace at rate of $10{ }^{\circ} \mathrm{C} / \mathrm{min}$ down to $600{ }^{\circ} \mathrm{C}$ and air cooling to room temperature. These heat-treatment conditions were chosen in accordance with the binary Ti-Au phase diagrams [16].

\section{Material characterization}

Phase analysis and structural characterization were performed by X-ray diffraction. The X-ray diffraction (XRD) patterns were collected for bulk samples using a X'Pert PRO Multi Purpose X-ray Diffractometer (40 kV and $40 \mathrm{~mA}$ ) with $\mathrm{Cu} \mathrm{K}_{\alpha}$ $(\lambda=1.54056 \AA)$. The scanning speed was $2 \% \mathrm{~min}$, and the scanning $2 \theta$ angle ranges from $20^{\circ}$ to $80^{\circ}$. The cp-Ti was used as a control. The lattice parameters were obtained by least squares refinement of data in the $2 \theta$ range of $20-80^{\circ}$ with the aid of a Rietveld refinement program [17]. The phase transformation of $\mathrm{Ti}-\mathrm{xAu}$ alloys was investigated by heating approximately $200 \mathrm{mg}$ of the sample to $1,000{ }^{\circ} \mathrm{C}$ at a rate of $20^{\circ} \mathrm{C} / \mathrm{min}$ using differential scanning calorimetry (DSC; DSC 404 C, Netzsch, Germany). The microstructures of samples were examined using metallurgical microscope (Epiphot FX35WA, Nikon, Japan), scanning electron microscope (SEM; Hitachi, S-3000 N, Japan), high-resolution transmission electron microscopy (HRTEM; Philips, TECHNAI-F20, Netherlands), selected area energy diffraction (SAED), and energy dispersive X-ray analysis (EDX; EMAX, Horiba, Japan). The elemental distribution of the $\mathrm{Au}$ and $\mathrm{Ti}$ in the alloys was mapped using the electron probe microanalysis (EPMA; Shimadzu, EPMA-1600, Japan). The microhardness of polished alloys was measured using a Vickers microhardness tester (Zwick, Postfach4350, Germany) with a 500-g load for $30 \mathrm{~s}$. Elastic modulus was measured using a Nanoindenter XP (MTS Co, USA) with a maximum indentation depth of $2 \mu \mathrm{m}$.

To observe the corrosion behavior of Ti-xAu alloys, potentiodynamic anodic polarization tests were conducted at a scan rate of $5 \mathrm{mV} / \mathrm{s}$ from $-1.5 \mathrm{~V}$ saturated calomel electrode (SCE) to $+1.5 \mathrm{~V} \mathrm{SCE}$ using a potentiostat (WAT100, WonA Tech Co., Ltd, Korea) in a $0.9 \% \mathrm{NaCl}$ solution at $37 \pm 1{ }^{\circ} \mathrm{C}$. A three-electrode cell was used. The counter electrode was a high-density graphite electrode, and the reference electrode was a SCE. Before immersing the test sample, the electrolyte was bubbled with Ar gas at $150 \mathrm{~mL} \mathrm{~min}^{-1}$ for more than $20 \mathrm{~min}$ to eliminate the residual oxygen in the electrolyte. The used electrolyte was replaced with the fresh electrolyte before each measurement. Both corrosion density and potential were estimated by Tafel plots using both the anodic and cathodic branches. At least three samples were tested to confirm the repetition of the experimental results.

The galvanic current density of various $\mathrm{Ti}-\mathrm{xAu} / \mathrm{cp}-\mathrm{Ti}$ galvanic pairs were measured over a 20-min period using a potentiostat/galvanostat under deaerated conditions (ZIVE SP2, WonA Tech). The experimental setup 
for the electrochemical measurements consisted of a three-electrode cell with the sample as a working electrode with exposed area of $0.79 \mathrm{~cm}^{2}$, a SCE as a reference electrode, and a cp-Ti as a counter electrode. The distance between the cp-Ti and the samples was maintained at $1 \mathrm{~cm}$.

\section{Results and discussion}

Phase and microstructure

X-ray diffraction (XRD) analysis was conducted for characterizing the phase of the cast alloy by matching each characteristic peak with the JCPDS files. The X-ray diffraction patterns as a function of $x$ for the Ti-xAu $(x=5,10,15,20$, and $40 \mathrm{wt} \%$ ) samples are shown in Fig. 1, and are compared with those of cp-Ti. The cp-Ti showed a hexagonal closepacked (hcp) crystal $\alpha$ phase structure whose unit cell constants were $a=2.959(1) \AA$ and $c=4.703(1) \AA(c / a$ ratio= $1.589)$, and they corresponded well with those in the literature (JCPDS card no. 44-1294). It could be clearly seen that the phases/crystal structure of the binary $\mathrm{Ti}-\mathrm{xAu}$ alloy was sensitive to the Au contents in the cast alloy. The Ti-xAu $(x=5$, 10 , and $15 \mathrm{wt} \%$ ) alloys were comprised mainly of $\alpha$-Ti phase. When the Au content was increased to $20 \mathrm{wt} \%$ or greater, the phase constitution was changed from a single $\alpha$-Ti phase to a mixture of $\alpha$-Ti phase and the secondary phase of $\mathrm{Ti}_{3} \mathrm{Au}$. As indicated by the intensity of the $\mathrm{Ti}_{3} \mathrm{Au}$ peaks in the XRD

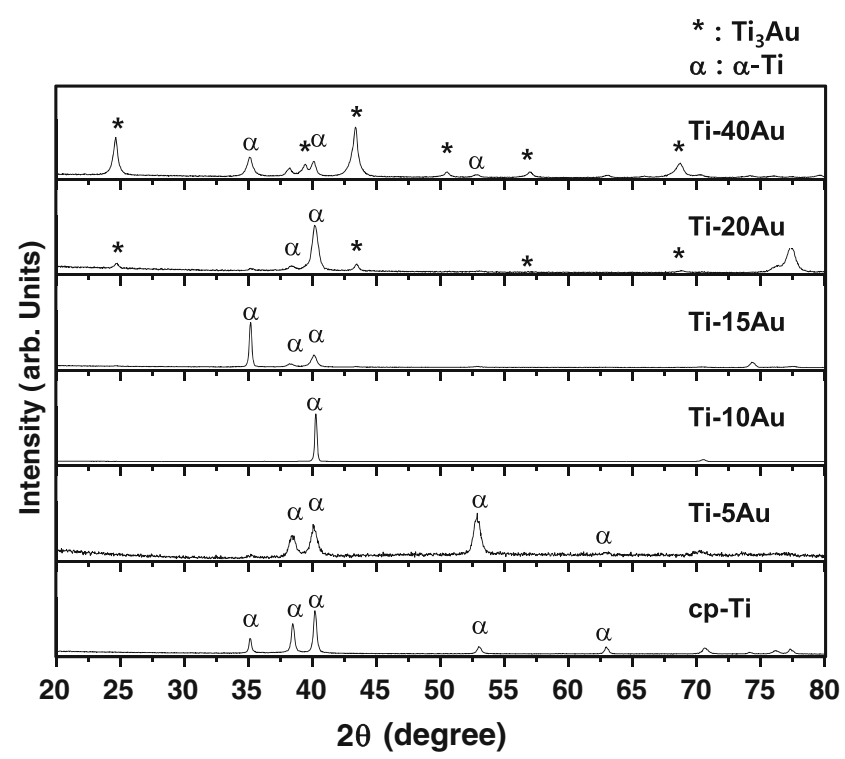

Fig. 1 XRD patterns of $\mathrm{cp}-\mathrm{Ti}$ and the series of binary Ti-xAu alloys ( $\alpha$ and $*$ represent diffraction peaks of the $\alpha$-Ti and $\mathrm{Ti}_{3} \mathrm{Au}$, respectively) patterns, the secondary phase of $\mathrm{Ti}_{3} \mathrm{Au}$ increased with the increase of $\mathrm{Au}$ contents. According to the equilibrium-phase diagram of the $\mathrm{Ti}-\mathrm{Au}$ system, the $\mathrm{Ti}-\mathrm{Au}$ alloy has a eutectoid point of $\alpha$-Ti and $\mathrm{Ti}_{3} \mathrm{Au}$ at $15.3 \% \mathrm{Au}[4,16]$. Therefore, the precipitation of the intermetallic compound $\mathrm{Ti}_{3} \mathrm{Au}$ was expected to occur at an $\mathrm{Au}$ concentration of approximately $15 \mathrm{wt} \%$ or more. Even though the $\mathrm{Ti}_{3} \mathrm{Au}$ phase was not detected in the Ti-15Au sample using XRD due to the detection limit of this instrument, the presence of $\mathrm{Ti}_{3} \mathrm{Au}$ phase was confirmed by SEM and transmission electron microscopy (TEM) at this Au concentration.

It is widely known that the mechanical properties of $\mathrm{Ti}$ alloys depend essentially on the microstructure. A good understanding of the microstructure of $\mathrm{Ti}$ alloys is therefore a prerequisite for controlling their properties. To investigate the influence of the addition of $\mathrm{Au}$ on the microstructures of $\mathrm{Ti}$, samples were investigated using metallurgical microscope and scanning electron microscope (SEM). Figure 2 shows the microstructures of $\mathrm{Ti}-\mathrm{xAu}$ alloys with different $\mathrm{Au}$ contents $(5,10,15,20$, and $40 \mathrm{wt} \%)$. The Ti-5Au and Ti-10Au alloys exhibited typical lath-type morphologies with a hexagonal crystal structure of the $\alpha$ phase. When the Au content was $15 \mathrm{wt} \%$, the alloy had an equiaxed structure and the secondary phase of $\mathrm{Ti}_{3} \mathrm{Au}$ was observed in alloys. From Fig. 2d, e, it was observed that $\mathrm{Ti}_{3} \mathrm{Au}$ was homogeneously distributed in the $\alpha$-Ti matrix, and the volume fraction of $\mathrm{Ti}_{3} \mathrm{Au}$ phase increased with the increase in Au content. The compositional analyses were performed using EDX at various areas marked in Fig. 2, and the results are summarized in Table 1. With the aid of EDX and TEM analysis, the bright region in the SEM micrographs of Fig. 2 was associated with the Au-rich phase $\left(\mathrm{Ti}_{3} \mathrm{Au}\right.$ phase), and the dark region was the Ti matrix ( $\alpha$-Ti phase).

At a lower $\mathrm{Au}$ concentration, only the $\alpha$-Ti phase was detected using the XRD. However, when the minimal amount of intermetallic compounds is existed in the alloy, it is difficult to detect the phases by using XRD due to instrumental detection limit. Therefore, in order to study the homogeneity of the microstructure of the $\mathrm{Ti}-5 \mathrm{Au}$ and $\mathrm{Ti}-10 \mathrm{Au}$ alloys, the elemental distribution of $\mathrm{Au}$ and $\mathrm{Ti}$ in the alloys was mapped by using the EPMA. Figure 3 shows the SEM backscattered electron image of $\mathrm{Ti}-\mathrm{xAu}(x=5,10$, and 15) alloys and the EPMA chemical analysis of Au elements. Imaging the polished $\mathrm{Ti}-\mathrm{xAu}$ alloys using backscattered electrons revealed the presence of two different phases. As darker spots represented the lighter elements in the backscattered image, Ti-rich phases were observed as dark spots, whereas the bright area was the Au-rich phase. EPMA mappings of the polished sample surfaces were also carried out to show the distribution of alloying elements in the phases. As the brighter area indicated a high concentration region of $\mathrm{Au}$ element, elemental 
Fig. 2 Micrographs of Ti-xAu alloys a $\mathrm{Ti}-5 \mathrm{Au}, \mathbf{b} \mathrm{Ti}-10 \mathrm{Au}, \mathbf{c} \mathrm{Ti}-$ $15 \mathrm{Au}, \mathbf{d} \mathrm{Ti}-20 \mathrm{Au}$, and e Ti-40Au. In each micrograph, the left images were metallurgical micrographs $(\times 400$; scale bar $10 \mu \mathrm{m})$ and the right images were SEM micrographs (scale bar $50 \mu \mathrm{m}$ ). The boxed letters denote the areas for compositional analyses using EDX.
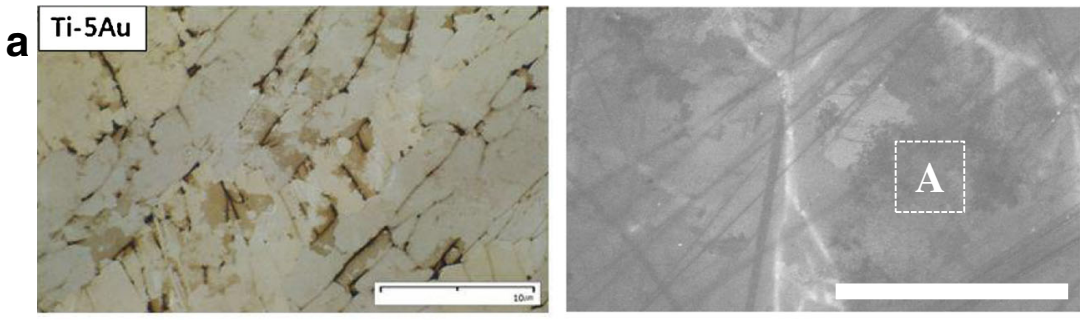

b
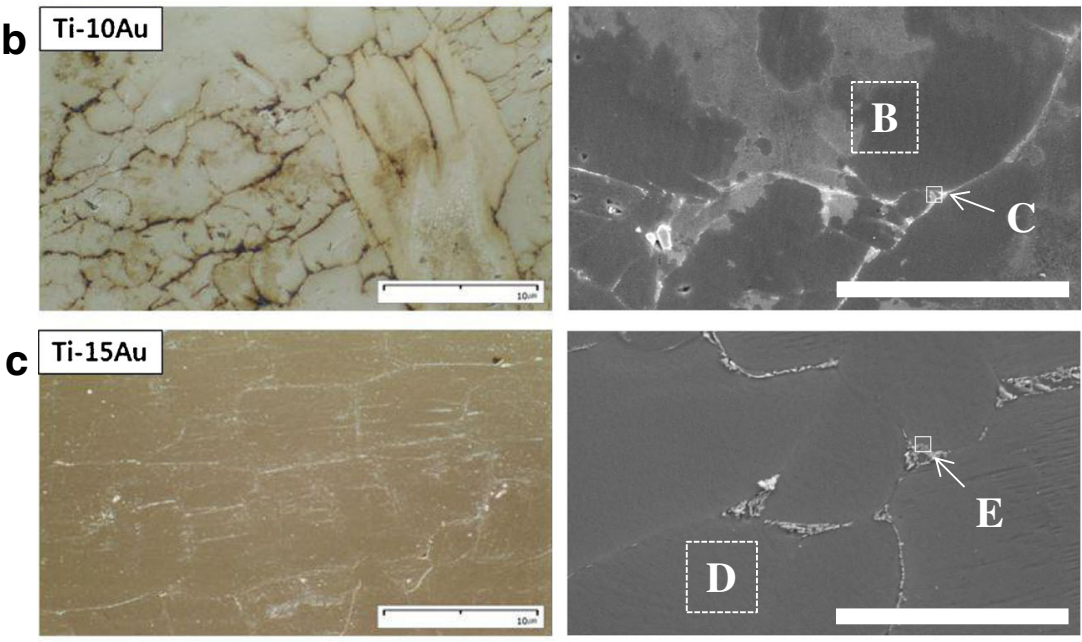

d
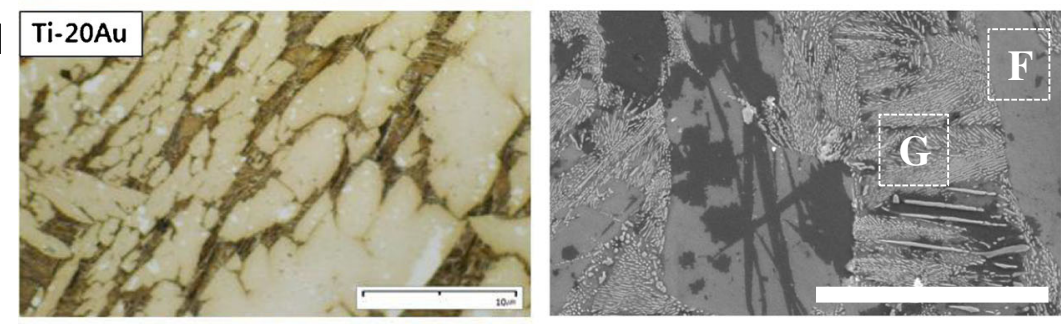

e
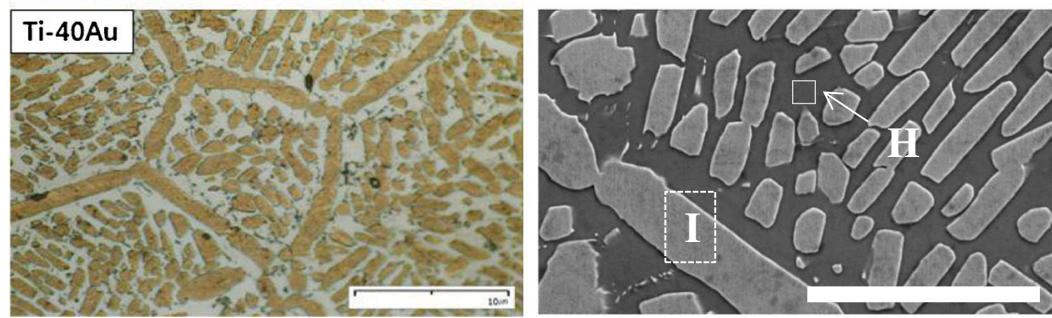

Table 1 Compositional analysis at areas shown in Fig. 2 for $\mathrm{Ti}-\mathrm{xAu}$ alloys

\begin{tabular}{lll}
\hline Alloy code & Area & Au (wt\%) \\
\hline Ti-5Au & A & 5.7 \\
Ti-10Au & B & 10.8 \\
& C & 16.9 \\
Ti-15Au & D & 12.8 \\
& E & 72.9 \\
Ti-20Au & F & 22.1 \\
& G & 49.5 \\
Ti-40Au & H & 16.5 \\
& I & 65.9 \\
\hline
\end{tabular}

mapping images showed that the Au-rich phase was concentrated at the interface.

Detailed analysis of phases was conducted using TEM. Typical representative TEM images and SAED patterns of the Ti-10Au and Ti-20Au alloys are shown in Fig. 4. The SAED patterns acquired from the regions marked as " $\mathrm{A}$ " and "B" in the TEM image of Ti-10Au alloy were obtained from $[413]_{\alpha}$ zone axis of a hexagonal $\alpha$-Ti structure, indicating that the Ti-10Au alloy was comprised mainly of $\alpha$-Ti phase. The SAED patterns acquired from the regions marked as " $C$ " and "D" in the TEM image of Ti-20Au alloy were obtained from $[213]_{\alpha}$ and $[100]_{\alpha}$ zone axis of a hexagonal $\alpha$-Ti structure, respectively. Whereas, the SAED pattern acquired from the 
Fig. 3 SEM backscattered electron images (BEI) and EPMA elemental maps for $\mathrm{Au}$ of a Ti$5 \mathrm{Au}, \mathbf{b} \mathrm{Ti}-10 \mathrm{Au}$, and $\mathbf{c} \mathrm{Ti}-15 \mathrm{Au}$ alloys
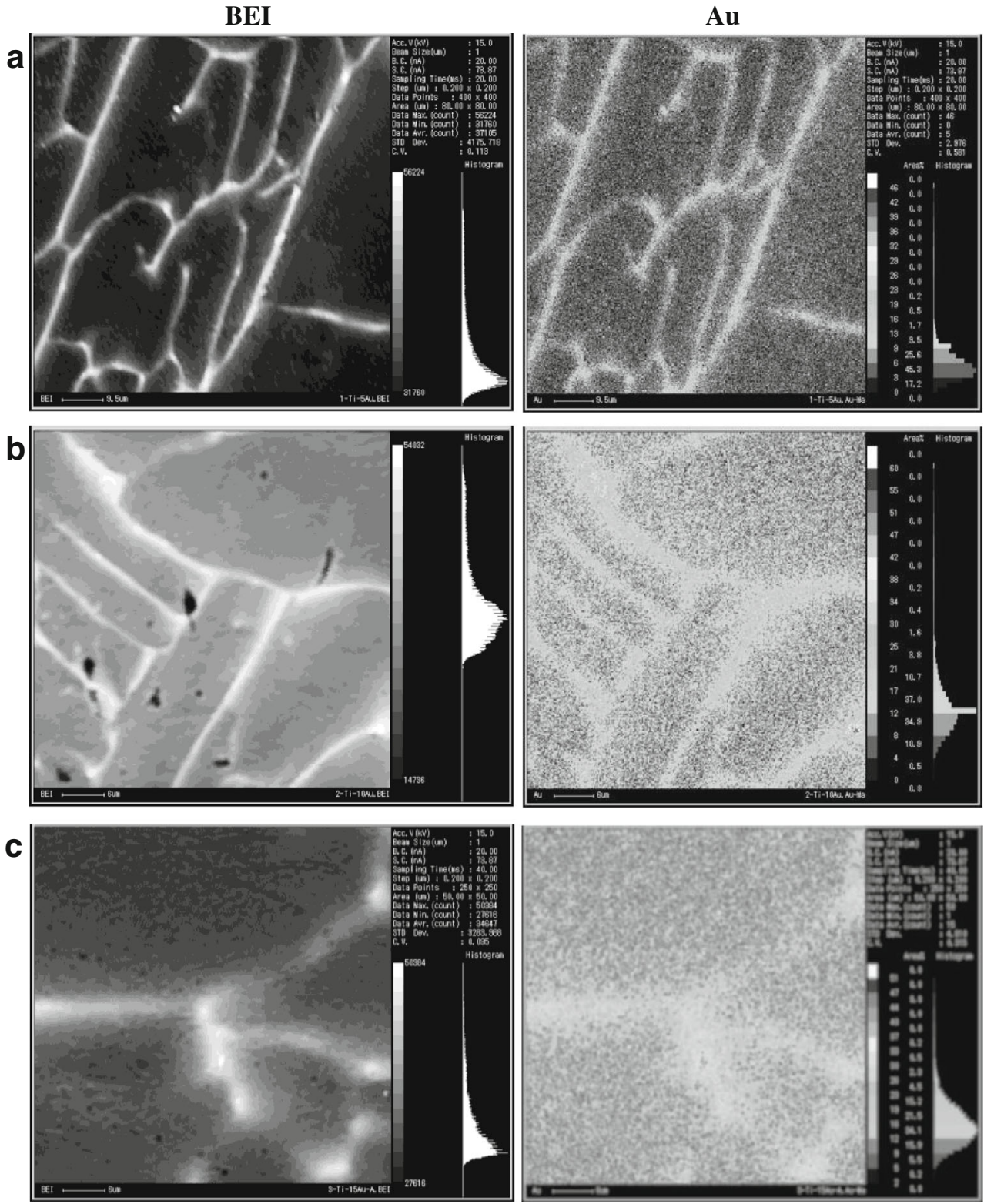

"E" region consisted of characteristic single-crystalline bcc $\mathrm{Ti}_{3} \mathrm{Au}$ phase, and this finding was in good agreement with the XRD and EDX analysis results.

DSC analysis was performed to detect any abnormal thermal effects from room temperature to $1,000{ }^{\circ} \mathrm{C}$ which could be representative of the presence of free segregation of $\mathrm{Au}$ or intermetallic precipitates. As shown in Fig. 5, very smooth temperature-dependent traces were found at about $150{ }^{\circ} \mathrm{C}$ for all Ti-xAu alloys with the content up to $10 \mathrm{wt} \%$. This peak resulted from stabilization of a thermally unstable structure such as grain boundary relaxation or grain boundary reordering. The second exothermic peak at about $900{ }^{\circ} \mathrm{C}$ occurred due to the martensitic transformation of $\alpha$-Ti to $\beta$ Ti. Other than those two peaks, no extraneous exothermic or endothermic peaks were detected. The martensitic transformation temperature decreased with increasing Au content as shown in Fig. 5. This implies that Au enhanced the stability of the $\beta$-phase, thus lowering the transformation temperature. When the alloy contained $20 \mathrm{wt} \%$ or more $\mathrm{Au}$, the alloy showed an extraneous exothermic peak which resulted from the formation of the $\mathrm{Ti}_{3} \mathrm{Au}$ phase. There was a gradual decrease in enthalpy of the exothermic peaks in DSC with the addition of $\mathrm{Au}$ in $\mathrm{Ti}$ alloys. The decrease in enthalpy may be understood as a result of short-range chemical ordering in the Au containing alloys.

\section{Mechanical properties}

The effect of alloying element $\mathrm{Au}$ on the mechanical properties and corrosion behavior of Ti was investigated. As shown 

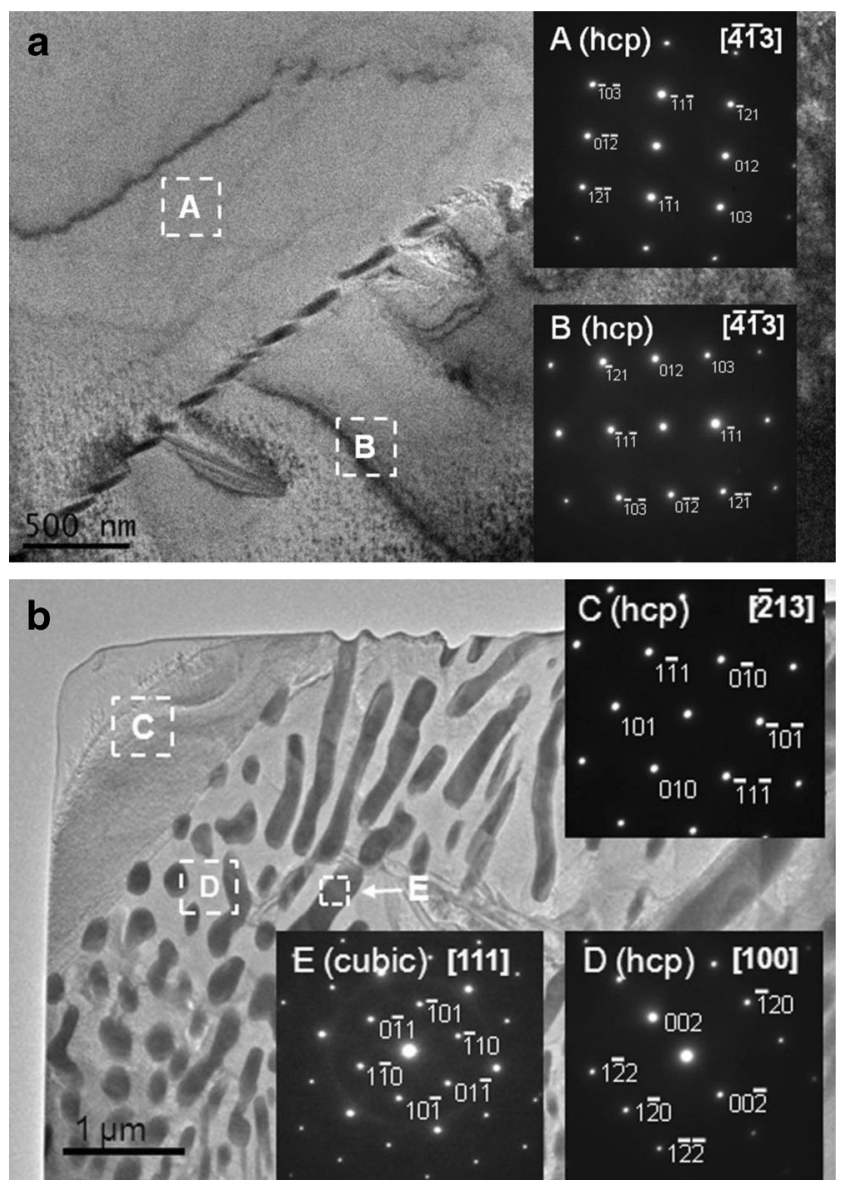

Fig. 4 TEM images and SAED patterns of a Ti-10Au and $\mathbf{b}$ Ti-20Au alloys

in Table 2, all of the Ti-Au alloys had significantly higher $(p<0.05)$ hardness than the cp-Ti. The hardness value tended to rise with increasing Au content up to $10 \mathrm{wt} \%$, which was mainly due to the solid-solution strengthening of the $\alpha$-phase. The VHN values for the alloys containing 5 and $10 \mathrm{wt} \% \mathrm{Au}$ were 375 and 343 , respectively. As for the Ti-15Au alloy, its microhardness was slightly decreased due to the formation of equiaxed structure. When the alloy contained $20 \mathrm{wt} \%$ or more

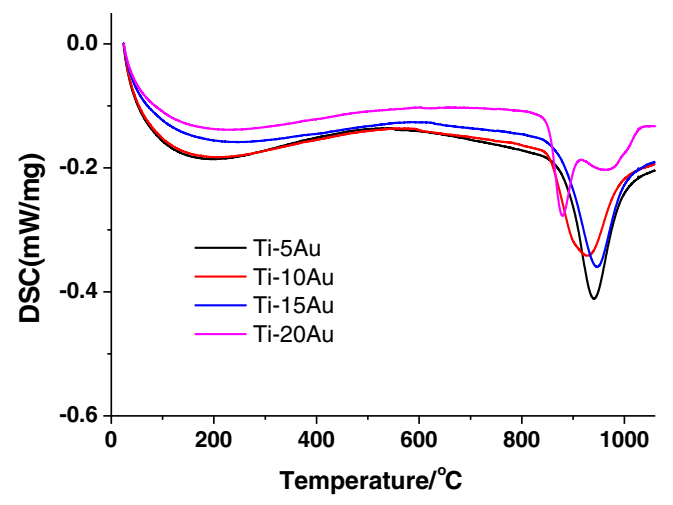

Fig. 5 DSC curves of the series of binary Ti-xAu alloys
Table 2 Hardness and elastic modulus values of Ti-xAu alloys compared with cp-Ti $(n=5)$

\begin{tabular}{lll}
\hline Alloy code & Vickers hardness (VHN) & Elastic modulus (GPa) \\
\hline cp-Ti & $164.54(3.54)^{\mathrm{a}} \mathrm{a}$ & $132.35(12.22) \mathrm{a}$ \\
$\mathrm{Ti}-5 \mathrm{Au}$ & $375.40(8.71) \mathrm{d}$ & $130.51(2.57) \mathrm{a}$ \\
$\mathrm{Ti}-10 \mathrm{Au}$ & $343.40(15.34) \mathrm{c}$ & $127.40(7.61) \mathrm{a}$ \\
$\mathrm{Ti}-15 \mathrm{Au}$ & $318.60(10.01) \mathrm{b}$ & $134.17(2.61) \mathrm{a}$ \\
$\mathrm{Ti}-20 \mathrm{Au}$ & $366.40(30.05) \mathrm{d}$ & $128.55(3.87) \mathrm{a}$ \\
$\mathrm{Ti}-40 \mathrm{Au}$ & $433.20(15.77) \mathrm{e}$ & $162.40(4.66) \mathrm{b}$
\end{tabular}

Different letters within same column indicate statistically significant difference at $5 \%(p<0.05)$

${ }^{\mathrm{a}}$ Mean (S.D.)

$\mathrm{Au}$, the microhardness values increased again. This increase in hardness was probably caused by the formation of a eutectoid structure consisting of $\alpha$-Ti and the intermetallic $\mathrm{Ti}_{3} \mathrm{Au}$ compound. A similar precipitation hardening was observed previously in the Ti-7Cr system [18] and Ti-30Nb system [19].

The results of elastic modulus measured by nanoindentation are also shown in Table 2. The elastic modulus for cp-Ti was $\sim 130 \mathrm{GPa}$. In the present study, the elastic moduli values for $\mathrm{Ti}-\mathrm{xAu}(x=5,10,15$, and 20$)$ alloys were in the range of 124-132 GPa. For these compositions, there was no statistically significant difference between Ti-xAu alloys $(p<0.05)$ and cp-Ti. However, the Ti-40Au alloy exhibited significantly high values of the elastic modulus $(164 \mathrm{GPa})$ due to the presence of the intermetallic $\mathrm{Ti}_{3} \mathrm{Au}$ alloy.

\section{Corrosion behavior}

The purpose of this study was to evaluate the corrosion resistance of experimental Ti-Au alloys. Potentiodynamic

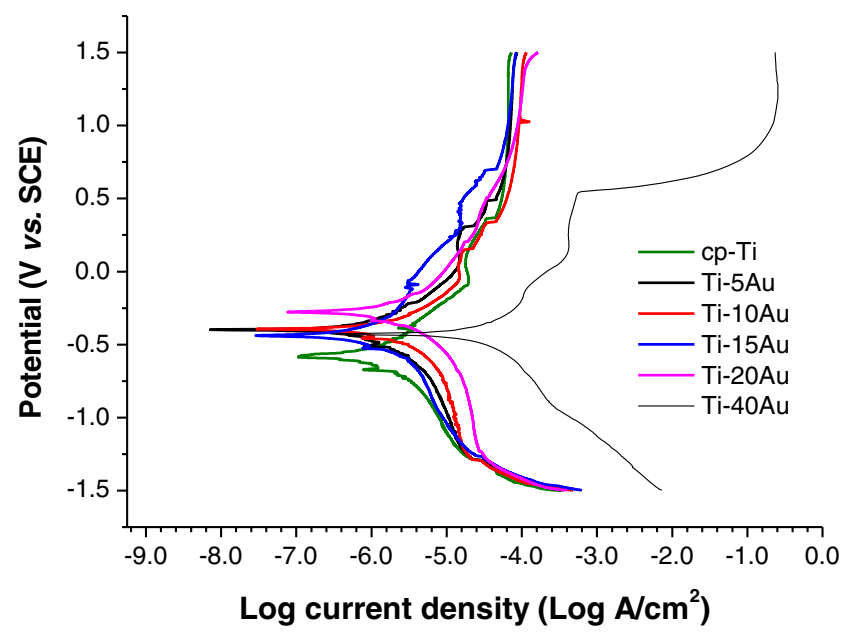

Fig. 6 Representative potentiodynamic polarization curves for $\mathrm{cp}$-Ti and Ti-xAu alloys 
Table 3 Corrosion potential $\left(E_{\text {corr }}\right)$ and corrosion current density $\left(I_{\text {corr }}\right)$ of cp-Ti and Ti-xAu alloys $(n=3)$

\begin{tabular}{lll}
\hline Alloy code & $E_{\text {corr }}(\mathrm{mV})$ & $I_{\text {corr }}\left(\mu \mathrm{A} / \mathrm{cm}^{2}\right)$ \\
\hline cp-Ti & $-575.00(40.95)^{\mathrm{a}} \mathrm{a}$ & $0.61(0.17) \mathrm{a}$ \\
$\mathrm{Ti}-5 \mathrm{Au}$ & $-462.67(59.76) \mathrm{b}$ & $0.29(0.08) \mathrm{a}$ \\
$\mathrm{Ti}-10 \mathrm{Au}$ & $-395.00(23.64) \mathrm{b}$ & $0.43(0.11) \mathrm{a}$ \\
$\mathrm{Ti}-15 \mathrm{Au}$ & $-472.67(90.01) \mathrm{b}$ & $0.36(0.14) \mathrm{a}$ \\
$\mathrm{Ti}-20 \mathrm{Au}$ & $-278.33(20.43) \mathrm{c}$ & $0.94(0.70) \mathrm{a}$ \\
$\mathrm{Ti}-40 \mathrm{Au}$ & $-425.73(63.40) \mathrm{b}$ & $7.78(6.51) \mathrm{b}$ \\
\hline
\end{tabular}

Within the same column, mean values with the same letters were not statistically different at $5 \%(p<0.05)$

${ }^{\mathrm{a}}$ Mean (S.D.)

polarization and galvanic couple technique were used in order to investigate the effect of $\mathrm{Au}$ content on corrosion resistance. The potentiodynamic polarization curves of $\mathrm{cp}$ $\mathrm{Ti}$ and $\mathrm{Ti}-\mathrm{xAu}$ alloy were recorded at a sweep rate of $0.005 \mathrm{~V} / \mathrm{s}$, between -1.5 and $1.5 \mathrm{~V}$ potential ranges in $0.9 \% \mathrm{NaCl}$ solutions, and the results are shown in Fig. 6. All curves exhibited active-passive behavior with apparently small oscillation of current density. These regions might be associated with the formation of one or more protective films. Except for the case of $40 \mathrm{wt} \%$ Au addition, all of the Ti-xAu alloys revealed that the initial passive current densities occurred in the range of 1.5 to $2.5 \times$ $10^{-5} \mathrm{~A} / \mathrm{cm}^{2}$. These current density values were similar to that of cp-Ti $\left(1.8 \times 10^{-5} \mathrm{~A} / \mathrm{cm}^{2}\right)$. At the potential of $0.55 \mathrm{~V}$, the current densities were in the following order: $\mathrm{Ti}-40 \mathrm{Au}$ $\left(5.7 \times 10^{-4} \mathrm{~A} / \mathrm{cm}^{2}\right)>\mathrm{Ti}-10 \mathrm{Au}\left(6.8 \times 10^{-5} \mathrm{~A} / \mathrm{cm}^{2}\right)>\mathrm{cp}-\mathrm{Ti} \approx$ $\mathrm{Ti}-5 \mathrm{Au}\left(5.0 \times 10^{-5} \mathrm{~A} / \mathrm{cm}^{2}\right)>\mathrm{Ti}-20 \mathrm{Au}\left(4.0 \times 10^{-5} \mathrm{~A} / \mathrm{cm}^{2}\right)>$ Ti-15Au $\left(2.0 \times 10^{-5} \mathrm{~A} / \mathrm{cm}^{2}\right)$. This trend of abrupt increase of current density in Ti-40Au at approximately $0.55 \mathrm{~V}$ (vs. SCE) agreed with the result of previous report [14].

Using the Tafel extrapolation method, we calculated corrosion potential $\left(E_{\text {corr }}\right)$ and corrosion current density $\left(I_{\text {corr }}\right)$ of cp$\mathrm{Ti}$ and Ti-xAu alloys from both the anodic and the cathodic branches of the potentiodynamic polarization curves, as listed

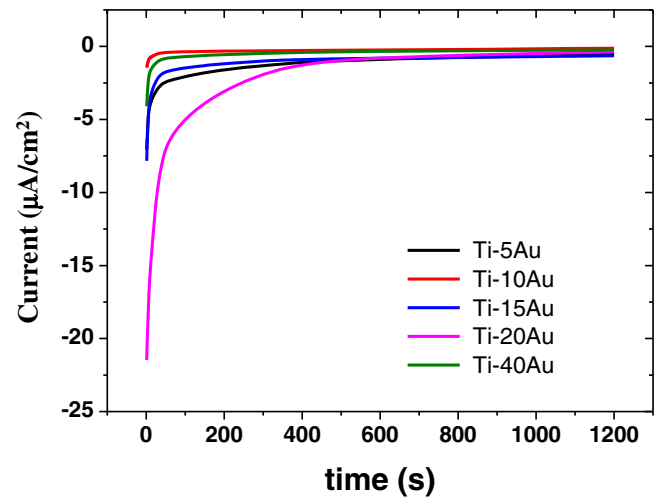

Fig. 7 Mean values of galvanic current density versus time of the couplings cp-Ti/Ti-xAu alloys in Table 3. Positive shifts in $E_{\text {corr }}$ were observed in all of the $\mathrm{Ti}-\mathrm{xAu}$ alloys, indicating a better corrosion resistance of the coated samples. The results showed that the Ti-20Au alloy had the most positive $E_{\text {corr }}$ value $(-0.278 \mathrm{~V})$. In comparison with $\mathrm{cp}-\mathrm{Ti}$, Ti-XAu alloys $(x=5,10$, and $15 \mathrm{wt} \%)$ exhibited slightly reduced current density values. When Au content was increased to more than $20 \mathrm{wt} \%$, the $I_{\text {corr }}$ increased from $0.94 \mu \mathrm{A} / \mathrm{cm}^{2}$ (Ti-20Au) to $7.78 \mu \mathrm{A} / \mathrm{cm}^{2}$ (Ti-40Au) due to the preferential attack of the $\mathrm{Ti}_{3} \mathrm{Au}$ phase. This finding was consistent with the previous report showing that the corrosion resistance of the Ti-Au alloys was deteriorated due to the preferential dissolution of $\mathrm{Ti}_{3} \mathrm{Au}$ [20]. From this experiment, it could be known that the presence of $\mathrm{Ti}_{3} \mathrm{Au}$ in $\mathrm{Ti}-\mathrm{Au}$ alloy not only cause an increase of corrosion potential but also weaken the passive film.

The passivation phenomenon might be studied better by the galvanic couple technique. Mean values of galvanic current densities versus the time of coupling in $\mathrm{cp}-\mathrm{Ti} / \mathrm{Ti}-\mathrm{xAu}$ alloys are shown in Fig. 7. Ti-xAu alloys apparently exhibited negative current values, indicating that the electron flows from cp-Ti to Ti-xAu alloy, thus causing corrosion of the cp-Ti, because it lost electrons. The galvanic current density increased with time and reached a stable value. This increase in the galvanic current density could be attributed to the formation of $\mathrm{a} \mathrm{TiO}_{2}$ product film on the cp-Ti surface which grew with time and partially protected this material. The Ti$10 \mathrm{Au}$ alloy showed the fastest cathodic behavior among the Ti-XAu alloys, since the time taken by the Ti-10Au alloys to attain the stable resting potential was less as compared to that taken by other Ti-xAu alloys.

\section{Conclusions}

The effect of Au alloying element on the microstructure, mechanical properties, and corrosion behavior of commercially pure titanium (cp-Ti) was investigated. Based on the results of XRD, EPMA, and optical microscopy, the Ti-xAu alloys with up to $10 \mathrm{wt} \% \mathrm{Au}$ content showed hep $\alpha$ structures, and the Ti-xAu alloys ( $x=15,20$, and $40 \mathrm{wt} \%)$ were composed of $\alpha$-Ti and $\mathrm{Ti}_{3} \mathrm{Au}$ intermetallic phases. As results of solid-solution strengthening of $\alpha$-Ti and precipitation hardening with $\mathrm{Ti}_{3} \mathrm{Au}$ intermetallic compound, the Ti-xAu alloys showed better hardness than the cp-Ti. The Ti-xAu alloys showed a higher corrosion resistance. After considering all the mechanical properties and corrosion behavior of the $\mathrm{Ti}-\mathrm{xAu}$ alloys, the Ti alloy with $10 \mathrm{wt} \%$ $\mathrm{Au}$ is a good candidate for dental casting materials. Due to the fact that $\mathrm{Ti}-\mathrm{Au}$ alloys have better hardness and corrosion resistance compared to conventional titanium, further investigation on the effects of compositional variations with less $\mathrm{Au}$ content in $\mathrm{Ti}-\mathrm{xAu}$ alloy systems for the possible application as implant materials might be needed. 
Acknowledgments This research was supported by the National Research Foundation of Korea (NRF) grant funded by the Korea government (MSIP) (No. 2011-0030762) and by the Basic Science Research Program through the NRF funded by the Ministry of Education, Science and Technology (2011-0002706).

Open Access This article is distributed under the terms of the Creative Commons Attribution License which permits any use, distribution, and reproduction in any medium, provided the original author(s) and the source are credited.

\section{References}

1. Leyens C, Peters M (2003) Titanium and titanium alloys. Wiley, New York

2. Lloyd C, Scrimgeour S, Brown D, Clarke R, Curtis R, Hatton P, Ireland A, McCabe J, Nicholson J, Setcos J (1997) Dental materials: 1995 literature review. J Dent 25:173-208

3. Ezugwu E, Wang Z (1997) Titanium alloys and their machinabilitya review. J Mater Process Technol 68:262-274

4. Niinomi M (1998) Mechanical properties of biomedical titanium alloys. Mater Sci Eng A 243:231-236

5. Rocher P, El Medawar L, Hornez J, Traisnel M, Breme J, Hildebrand $\mathrm{H}$ (2005) Biocorrosion and biocompatibility of NiTi alloys. Eur Cell Mater 9:23-24

6. Eisenbarth E, Velten D, Müller M, Thull R, Breme J (2004) Biocompatibility of $\beta$-stabilizing elements of titanium alloys. Biomaterials 25:5705-5713

7. Cremasco A, Messias AD, Esposito AR, Duek EAR, Caram R (2011) Effects of alloying elements on the cytotoxic response of titanium alloys. Mater Sci Eng C 31:833-839
8. Lide DR (1995) CRC handbook of chemistry and physics, 76th edn. CRC, Boca Raton

9. Knosp H, Holliday RJ, Corti CW (2003) Gold in dentistry: alloys, uses and performance. Gold Bull 36:93-102

10. Corti CW, Holliday RJ (2004) Commercial aspects of gold applications: from materials science to chemical science. Gold Bull 37:20-26

11. Takada Y, Ito M, Kimura K, Okuno O (2005) Electrochemical properties and released ions of $\mathrm{Au}-1.6$ mass\% Ti alloy. Dent Mater J 24:153-162

12. Fischer $J$ (2002) Effect of small additions of Ir on properties of a binary Au-Ti alloy. Dent Mater 18:331-335

13. Rosalbino F, Delsante S, Borzone G, Scavino G (2012) Influence of noble metals alloying additions on the corrosion behaviour of titanium in a fluoride-containing environment. J Mater Sc-Mater Med 23: $1129-1137$

14. Takahashi M, Kikuchi M, Okuno O (2004) Mechanical properties and grindability of experimental Ti-Au alloys. Dent Mater J 23:203210

15. Oh KT, Kang DK, Choi GS, Kim KN (2007) Cytocompatibility and electrochemical properties of Ti-Au alloys for biomedical applications. J Biomed Mater Res Part B 83:320-326

16. Murray JL (1987) Phase diagrams of binary titanium alloys. ASM International, Geauga County

17. Hunter B, Howard C (2000) Rietica; Australian Nuclear Science and Technology Organization: Menai. Australia

18. Koike M, Okabe T, Itoh M, Okuno O, Kimura K, Takeda O, Okabe TH (2005) Evaluation of Ti-Cr-Cu alloys for dental applications. J Mater Eng Perform 14:778-783

19. Kikuchi M, Takahashi M, Okuno O (2003) Mechanical properties and grindability of dental cast Ti-Nb alloys. Dent Mater J 22:328-342

20. Takahashi M, Kikuchi M, Takada Y, Okuno O, Okabe T (2004) Corrosion behavior and microstructures of experimental Ti-Au alloys. Dent Mater J 23:109-116 